\title{
Analyzing the Characteristics of Domestic Wastes in Belik River, the Special Region of Yogyakarta, Indonesia
}

\author{
Slamet Suprayogi ${ }^{1}$, Muh Aris Marfai ${ }^{1{ }^{*}}$, Ahmad Cahyadi ${ }^{1}$, Reviana Latifah ${ }^{1}$, and Hendy Fatchurohman ${ }^{2}$ \\ ${ }^{1}$ Department of Environmental Geography, Faculty of Geography, Universitas Gadjah Mada, Sekip Utara, Bulaksumur, Yogyakarta 55281, \\ Indonesia \\ ${ }^{2}$ Department of Geo-Informatics, Vocational College, Universitas Gadjah Mada, Sekip Unit 1 Catur Tunggal, Yogyakarta 55281, Indonesia \\ *Corresponding author: arismarfai@ugm.ac.id
}

KEYWORDS

Water quality

Domestic waste

Pollution

Belik River

Indonesia

\begin{abstract}
The multiplying number of population in the City of Yogyakarta has resulted in a larger volume of wastes in the region. People living on the riverbanks are unfortunately in the habit of discarding domestic waste directly to the river channel, worsening the already polluted water. This study was intended to analyze the characteristics of the municipal wastewater contaminating Belik River. During the water quality test, a rapid investigation method and laboratory analysis were employed. The sampling in the field was based on river segments and travel time of river water. Based on the laboratory test results, the concentrations of phosphate, BOD, and COD in the water bodies had exceeded the standard for Class II water quality indicating pollution due to frequent disposal of household wastes like detergents. The higher the BOD and COD levels, the more unsuitable the water for fisheries and agricultural practices.
\end{abstract}

(c) The Author(s) 2019. This article is distributed under a Creative Commons Attribution-ShareAlike 4.0 International license.

\section{INTRODUCTION}

Belik Sub-watershed is an urban area, stretching from Karangwuni in the north (around the campus of Universitas Gadjah Mada [UGM]) through densely populated areas in the City of Yogyakarta then to the south. As the population growth along Belik River accelerates-mainly due to migration, land-use conversion to residential areas becomes more extensive (Suprayogi 2017), and the total quantity of waste generated in the region unavoidably increases. There is a link between population and environmental degradation (Asrifah 2012; Puspita et al. 2016; Cahyo et al. 2016; Sutardi et al. 2017). When the riverbanks are increasingly occupied, it presumably affects the behavior of the people living on them (Abdi et al. 2011; Cahyadi 2019). For instance, they tend to discard domestic wastewater (i.e., from washing, cooking, and bathing) directly to the river (Setiawan et al. 2018). When prolonged, this practice can deteriorate the quality of the aquatic environment and add pressure to the capacity of, particularly, Belik River. Aside from water pollution, this river is faced with the narrowing of river channels that eventually leads to frequent flooding in Belik Sub-watershed.

Basically, various measures have been taken to overcome the flood problems in Belik Sub-watershed. An example includes a currently designed water plant in the north of the UGM campus that is expected to be able to prevent downstream flooding and Langensari Reservoir in the middle part of the sub-watershed. Nevertheless, these two engineering measures remain inefficient in managing the floods. Flooding often occurs even when runoff is evacuated to the water plant in a valley inside the UGM campus area because this channel cannot accommodate all water drained away from the settlements upstream, inundating a nearby busy road, Jl. Colombo. Similarly, the capacity of the Langensari Reservoir is often exceeded; hence, the water overflows onto the surrounding area, Klitren.

Although the two structures above are inefficient in flood control, they play a role in solving the water pollution problem in Belik River. Accordingly, their functions in the process of water self-purification from the contamination of household wastes need to be examined. Some of the wastes upstream enter the water plant in the UGM Valley, while the domestic wastes in the middle part of the subwatershed partly flow into the reservoir. In other terms, these wastes do not flow directly to the downstream area but are first accommodated in the water plant and reservoir. Runoff stays temporarily in these water buildings in which the pollutant loads are rinsed and allowed to settle, initiating the process of self-purification. This paper discusses the examined characteristics of domestic wastes in several segments of Belik River.

\section{METHOD}

\subsection{Study area}

This study was conducted in Belik Sub-watershed, which administratively consists of four subdistricts in the Special Region of Yogyakarta, namely Depok (in Sleman Regency), Gondokusuman, Pakualaman, and Umbulharjo (Yogyakarta City). It is located at the coordinates $431199-432733 \mathrm{mE}$ and 9135817-9142436 mN. Belik Sub-watershed covers an area of 683.79 ha, with Belik River as the primary channel passing through the sub-watershed. 


\subsection{Tools and materials}

This study employed field observations for spatial analysis and water sampling. The tools used were GPS, Abney level, measuring tape, water sample bottles, ranging rod, water checker, camera, computer, and stationery. As for the research material, it included Bing-satellite imagery of 2003 for detailed land cover analysis, 1:25.000 Indonesian Topographic Maps (2013), 1:25.000 land use map (2013), flow velocity in each river segment as the basis for water sampling, and data of water discharge flowing into the reservoir.

\subsection{Data collection and analysis techniques}

The secondary data were Bing-satellite images, while the primary data were obtained from the measurements of flow velocity and discharge, as well as water sampling. This sampling started from the upper part of Belik River to the urban areas, and the sampling sites were determined by considering the input flows from domestic wastes generated by the settlement areas and the presence of the water plant and reservoir. The river segments and water sampling points are presented in Figure 1. The flow velocity was calculated using the slope area method. Meanwhile, the water was sampled to analyze the characteristics of the domestic wastes polluting Belik River using the following procedure: (1) the river segments were divided into eight classes based on the density of the nearby settlements, and (2) water sampling from the first to the next segment took into account the travel time of the water. The water quality was tested in two ways, namely a rapid investigation to examine $\mathrm{pH}$, EC, TDS, salinity, and temperature and laboratory analysis that gauged other water quality parameters, such as nitrate $\left(\mathrm{NO}_{3}\right)$, sulfate $\left(\mathrm{SO}_{4}\right)$, phosphate $\left(\mathrm{PO}_{4}\right), \mathrm{BOD}$, and COD.

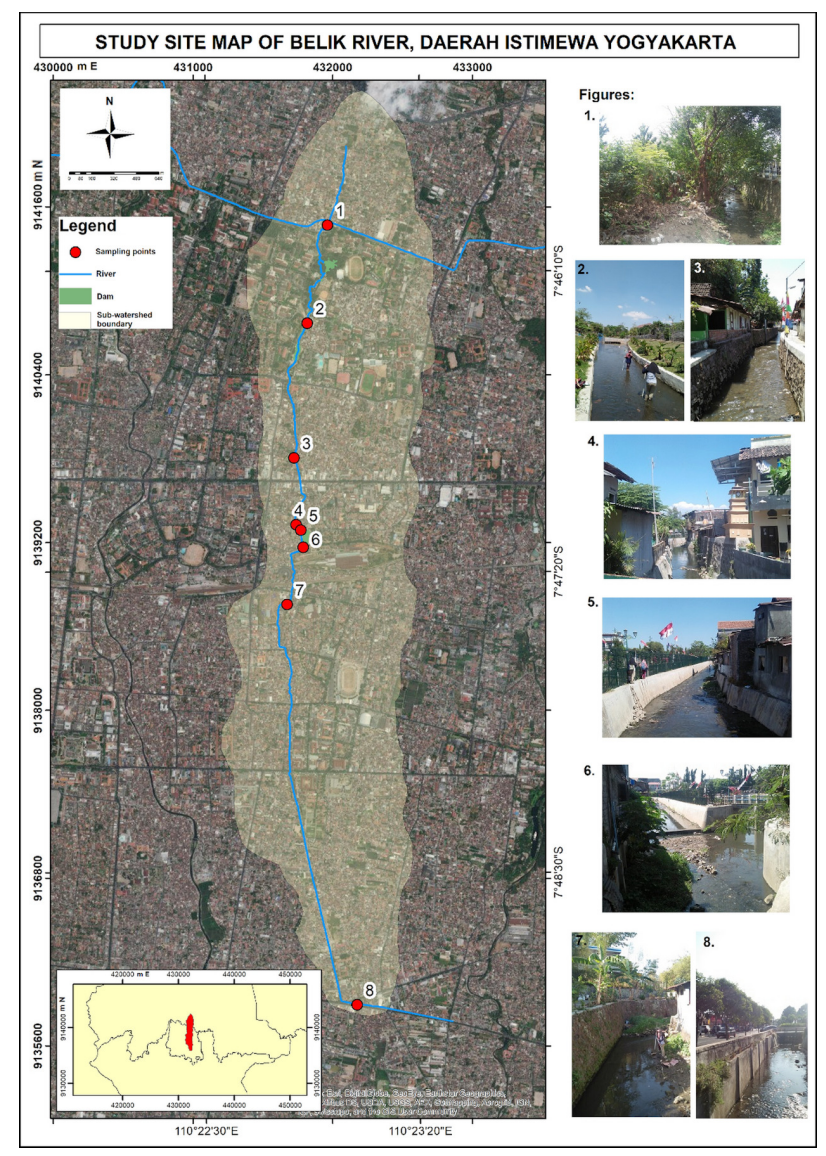

FIGURE 1. Water sampling sites in Belik River.
The travel time of water was calculated from the flow velocity of each predefined segment using Equation 1. Flow velocity method is suitable for this research because its consider the roughness coefficient, slope, and hydraulic radius.

$$
V=\frac{1}{n} R^{\frac{2}{3}} S^{\frac{1}{2}}
$$

where:

$\mathrm{V}=$ flow velocity $(\mathrm{m} / \mathrm{s})$

$n=$ Manning's coefficient of roughness

$\mathrm{R}=$ hydraulic radius $\mathrm{R}=\mathrm{A} / \mathrm{p} ; \mathrm{A}=$ wet cross-sectional area $\left(\mathrm{m}^{2}\right), \mathrm{p}=$ wetted perimeter $(\mathrm{m})$ $\mathrm{S}=$ channel slope

The travel time of water is the distance from the first water sampling point to the next one divided by flow velocity, as written in Equation 2 below.

$$
T=\frac{L}{V}
$$

where:

$\mathrm{T}=$ travel time of water (minute)

$\mathrm{L}=$ distance from point 1 to point $2(\mathrm{~m})$

$\mathrm{V}=$ flow velocity $(\mathrm{m} / \mathrm{s})$

\section{RESULTS AND DISCUSSION}

\subsection{Regional characteristics}

Belik is a sub-watershed in an urban area. Consequently, this region is rapidly developing, and the population growth rate increases from year to year. Population growth in the Special Region of Yogyakarta in 2011 recorded up to 0.86 /year with Sleman regency as the highest with $1.30 \%$ of growth. The city of Yogyakarta is the most populous region with more than 12.017 people $/ \mathrm{km}^{2}$ (Prihatin 2016). The establishment of a higher education campus in Yogyakarta supports this condition as it is a pulling factor for students from outside the region to continue their studies here and live close to the university. Growing population size means that the demand for shelter and basic needs, such as clean water for daily activities (i.e., domestic water needs), is also rising.

High demand for domestic water mostly results in an increased volume of household waste. Moreover, in urban areas, some economic activities also produce municipal waste (Shi et al. 2019). Belik Sub-watershed is mostly built-up land covering an area of 621.41 ha or $91 \%$ of the total area of the study site (i.e., 683.79 ha). This extensive built-up land generates domestic waste from its diverse utilization, including 174.58 ha of office space, 204.42 ha of settlements, 41.36 ha of shops and commercial establishments, and 87.75 ha of housing. The land use in Belik Subwatershed is presented in detail in Table 1 , and its spatial distribution is illustrated in Figure 2.

\subsection{Flow velocity and discharge}

The water of Belik River generally has a fluctuating flow velocity, as presented in Table 2. It is dependent on the conditions and slopes of the river channel that also vary from one location to the other. Point 1 had a flow velocity of $0.39 \mathrm{~m} / \mathrm{s}$, and this relatively calm water was attributable to the moderately flat riverbed with sediments covering it. This flow 
velocity produced a flow discharge of $0.076 \mathrm{~m}^{3} / \mathrm{s}$. At Point 2 , the flow velocity was faster, i.e., $0.77 \mathrm{~m} / \mathrm{s}$, because this river segment received input from the Mataram Channel, a primary water irrigation distributor in the Special Region of Yogyakarta, and had a higher slope gradient than Point 1. Traversing a straight channel (due to artificial embankments), the river flow was stable without any significant deceleration in its velocity. Contrary to any engineered channels, there are frictions of water in natural rivers against the plants and sediments on the banks. At a fast rate, the water influx from the Mataram Channel yielded a copious amount of discharge, up to $0.523 \mathrm{~m}^{3} / \mathrm{s}$.

The flow velocity at Point 3 was $0.67 \mathrm{~m} / \mathrm{s}$, and it discharged $0.361 \mathrm{~m}^{3} / \mathrm{s}$ water. This river segment had been engineered into a straight channel with embankments, as in Point 2, removing any effects of river meandering that slow down the water flow. In contrast, the flow velocity at Point 4 decelerated because of the impacts of river meanders and the proximity of the river to settlements. At this point, houses occupied the banks of the river. The flow velocity measured was $0.22 \mathrm{~m} / \mathrm{s}$, and it yielded $0.375 \mathrm{~m}^{3} / \mathrm{s}$ of water. Although the river at Points 3 and 4 flowed at different speeds, they produced a similar amount of discharge because the cross-sectional area at Point 4 was broader than Point 3.

The flow velocity at Point 5 was $0.57 \mathrm{~m} / \mathrm{s}$ and produced a discharge of $0.623 \mathrm{~m}^{3} / \mathrm{s}$. This point had sediments deposited on the banks (point bar), causing the river flow to

TABLE 1. Land utilization of Belik Sub-watershed based on 1:25.000 Indonesian Topographic Map.

\begin{tabular}{lc}
\hline Land Use & Area (ha) \\
\hline Vegetated & 56.81 \\
Yard (paved/covered with concrete) & 16.90 \\
Yard (sandy soil, flat ground) & 11.12 \\
Paved Road & 39.59 \\
Field & 7.90 \\
Cemetery & 7.66 \\
Office Complex & 174.58 \\
Settlement & 204.42 \\
Commercial Establishment & 41.36 \\
Housing & 87.75 \\
Playground & 1.40 \\
Empty Lot (sandy soil, flat ground) & 30.90 \\
Water Body & 3.39 \\
\hline Total & 683.79 \\
\hline
\end{tabular}

TABLE 2. Flow velocity and discharge data of Belik River.

\begin{tabular}{llll}
\hline \multicolumn{1}{c}{ Points } & $\begin{array}{c}\text { Flow } \\
\text { Velocity } \\
(\mathrm{m} / \mathrm{s})\end{array}$ & $\begin{array}{c}\text { Discharge } \\
\left(\mathrm{m}^{3} / \mathrm{s}\right)\end{array}$ \\
\hline 1 & (Kocoran) & 0.392 & 0.076 \\
2 & (Wisdom Park) & 0.766 & 0.523 \\
3 & (Gardena) & 0.667 & 0.361 \\
4 & (Before the Reservoir's Inlet) & 0.216 & 0.375 \\
5 & (Reservoir's Distributary) & 0.574 & 0.623 \\
6 & (Confluence of the Reservoir's Outlets) & 0.730 & 0.466 \\
7 & (Baciro) & 0.293 & 0.085 \\
8 & (XT Square) & 0.255 & 0.244 \\
\hline
\end{tabular}

accumulate on one side of the river bank and, consequently, faster flow than the previous point. Vegetation (grass) on the banks is not a determinant of the flow velocity at Point 5. As for Point 6 , it is the meeting point of the natural flow of Belik River and the water flow discharged from the reservoir. Due to this confluence, Point 6 had a rather fast flow, $0.73 \mathrm{~m} / \mathrm{s}$, that produced a discharge of $0.466 \mathrm{~m}^{3} / \mathrm{s}$. The same case was identified at Point 2 that received additional water release from the Mataram Channel. In the case of Point 6 , the river segment was also supplied by water from the reservoir's outlet. However, the high flow velocity at Point 6 did not produce a more significant amount of discharge than Point 5 because the wet cross-sectional area of the former was smaller than the latter.

At Point 7, the flow velocity was $0.29 \mathrm{~m} / \mathrm{s}$ and produced a flow rate of $0.085 \mathrm{~m}^{3} / \mathrm{s}$. The slow water flow resulted in small discharge, especially with a small cross-sectional area. These numbers were the result of water traversing meanders and the proximity of the water to the settlement. The low discharge was also caused by the existence of a flow-measuring weir upstream (i.e., under the bridge near the gas station) that stored but did not drain the water downstream optimally. The flow velocity at Point 8 was $0.26 \mathrm{~m} / \mathrm{s}$, which yielded $0.244 \mathrm{~m}^{3} / \mathrm{s}$ water. At Point 7 , the flow velocity was slow due to meanders and stream gauge station (weir), while the same flow velocity at Point 8 was attributable to the sloping river surface.

\subsection{Condition of $\mathrm{pH}, \mathrm{TDS}, \mathrm{EC}$, salinity, and temperature}

The degree of acidity $(\mathrm{pH})$ of Belik River ranged from 7.88 to 8.15 , which is alkaline $(\mathrm{pH}>7)$ (Asdak 1995). This alkaline water represents contamination by wastewater gener-

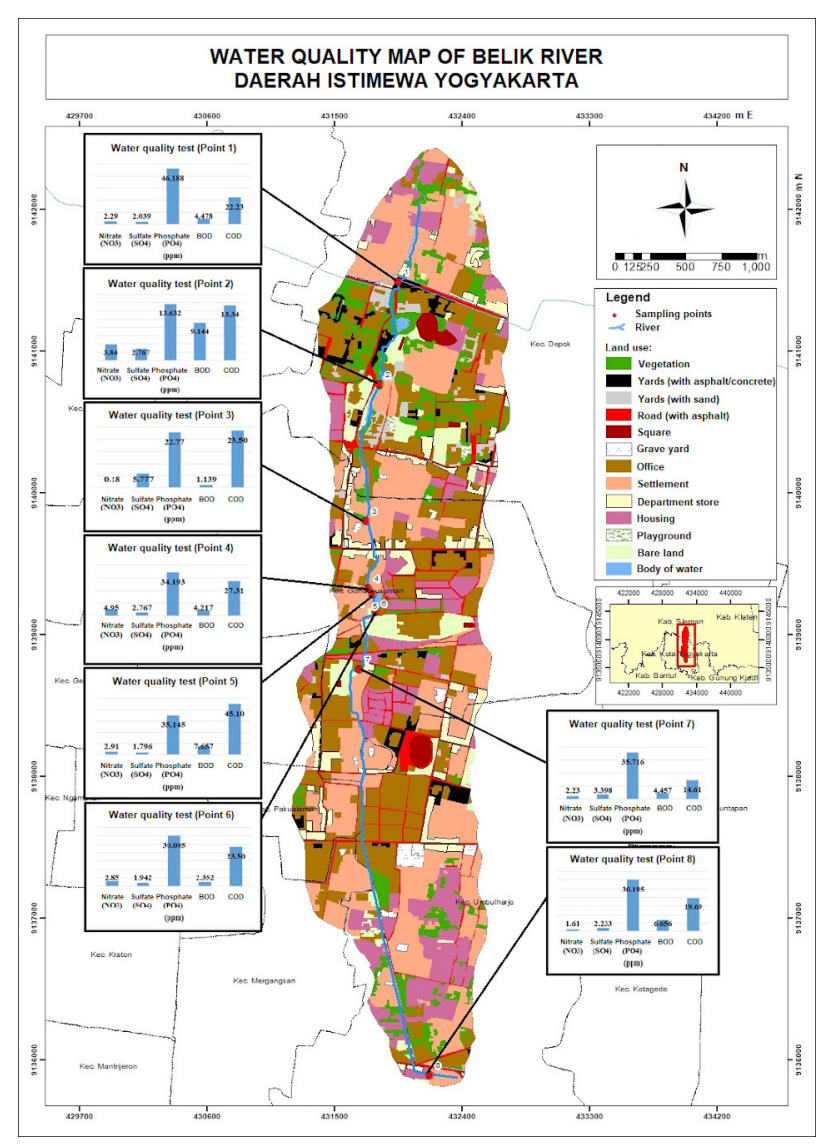

FIGURE 2. Water quality map of Belik River. 
ated by bathing, washing, and use of lavatory that is discarded directly into the river. The measured $\mathrm{pH}$ levels were still within the requirements for Class II (water recreation, freshwater fisheries, livestock, and irrigation purposes) water quality, i.e., 6-9 (Republic of Indonesia Government Regulation No. 82 of 2001).

Belik River contained Total Dissolved Solids (TDS) of 306-367 mg/l, with the highest TDS detected at Point 1. This categorically high TDS indicates erosion processes along the river or the transportation of solid materials by the flow. Here, dissolved solids comprise not only inorganic and organic compounds that are soluble in water but also minerals and their salts (Fardiaz 1992). Overall, from Points 2 to 8, the TDS of Belik River showed an increase because when the water sampling approached the last point, the time was late in the afternoon in which many human activities like washing and bathing took place and, therefore, stirred the dissolved matters in the water. Also, grass litter, believed to have been discarded after weed control, was found floating on the river during the sampling, increasing the water turbidity. According to the standard of Class II water quality in Yogyakarta, TDS must not exceed 1,000. Therefore, based on the TDS, the water of Belik River can still function as Class II water.

Electrical Conductivity (EC) depends on ion concentration and water temperature (Kuo et al. 2019). It means that an increase in TDS results in an elevation in EC. The EC of Belik River varied between $431 \mu$ mhos and $517 \mu$ mhos. The highest EC (517 $\mu$ mhos) was detected in Point 1, corresponding to the results of the TDS measurement, i.e., the most significant level of TDS was also found at Point 1 . Then, from Points 2 to 8 , the EC exhibited an increasing trend. This trend can be affected due to higher sediment contents to the downstream of the river.

The salinity of Belik River was between 0.17 and $0.2 \mathrm{ppt}$. This finding is in line with previous studies, which assert that freshwater has low or less than $0.5 \mathrm{ppt}$ of salt concentration (Effendi 2003). The salinity levels indicate that the observed river water is within the normal limits or without an excess of salt. The temperature of the Belik River was in the range of $27.5-30.2^{\circ} \mathrm{C}$. The results of the rapid water quality investigation of Belik River are presented in detail in Table 3.

\subsection{Nitrate, phosphate, and sulphate}

From the laboratory analysis in eight locations, the nitrate concentration $\left(\mathrm{NO}_{3}\right)$ was found to be in the range of 0.18$4.95 \mathrm{ppm}$. This range is still within the allowable presence of nitrate in Class II water requirements (Republic of Indonesia Government Regulation No. 82 of 2001). However, only Point 3 had a nitrate concentration of $0.18 \mathrm{ppm}$, while the other seven sampling sites contained $2 \mathrm{ppm}$ of nitrate or above. When nitrate is found higher than $0.2 \mathrm{ppm}$ in a water body, it can lead to eutrophication that further stimulates algal blooming and triggers an explosive growth of aquatic plants, such as water hyacinth (Effendi 2003). Nitrate $\left(\mathrm{NO}_{3}\right)$ is the main form of nitrogen in natural waters and is the primary source of nutrients for the growth of phytoplankton and other aquatic plants.

Phosphate concentrations $\left(\mathrm{PO}_{4}\right)$ of Belik River varied from 13.6 to $46.2 \mathrm{ppm}$, which are categorically high and have exceeded the Class II water quality standard, that is, 0.2 $\mathrm{ppm}$. Phosphate is produced in mineral rock weathering, organic matter decomposition, and the use of laundry detergents and fertilizers, and it most likely comes from other household waste, industrial waste, and phosphate minerals (Effendi et al. 2015). The main source of phosphate at the research location indicated from the use of detergents considering that the catchment area dominated by settlements. The highest phosphate level was identified at Point 1. This point represents an area occupied by dense settlements and the growing number of laundry business that intensify the use of detergents and contribute to the accumulation of phosphate in the river. Meanwhile, the sulfate concentrations of this river were in the range of 1.7-5.7 ppm, which are far below the Class II water quality standard in Yogyakarta, that is, 400 ppm. Kuo et al. (2019) stated that nitrate and phosphate represent the underlying water quality variations in agricultural cultivation zone.

\subsection{Biochemical oxygen demand (BOD) and chemical oxy- gen demand (COD)}

The range of biological oxygen demand (BOD) used in water quality analysis is usually in the range of $0.5-7.0 \mathrm{mg} / \mathrm{l}$ (Bianchi et al. 2019). Waters with BOD levels of higher than $10 \mathrm{mg} / \mathrm{l}$ are considered contaminated. In this study, the BOD of Belik River varied from 1.1 to $9.1 \mathrm{ppm}$, with low levels of BOD detected at Point 3 (1.1 ppm) and Point 6 (2.3 $\mathrm{ppm})$. The Class II water quality standard requires BOD of lower than or equal to $3 \mathrm{ppm}$. For this reason, other sampling sites except Points 3 and 6 are segments of Belik River whose BOD levels have exceeded the water quality standard and indicated pollution.

The laboratory test results also showed that the chemical oxygen demand (COD) was between 13.34 and $45.1 \mathrm{ppm}$. Points 4 and 5 had high COD, namely $27.3 \mathrm{ppm}$ and 45.1 ppm, respectively. Since the upper threshold of the allowable COD in Class II water is $25 \mathrm{ppm}$, the water at both points is categorized as polluted. A water body with high

TABLE 3. Results of the water quality test with a rapid investigation technique.

\begin{tabular}{|c|c|c|c|c|c|c|}
\hline No & Discharge $\left(\mathrm{m}^{3} / \mathrm{s}\right)$ & $\mathrm{pH}$ & EC & TDS & Salinity & Temperature \\
\hline \multicolumn{2}{|c|}{ Class II Water Standard } & $6-9$ & & 1,000 & & \\
\hline 1 & 0.076 & 8.14 & 517 & 367 & 0.207 & 27.5 \\
\hline 2 & 0.523 & 8.15 & 431 & 306 & 0.172 & 27.7 \\
\hline 3 & 0.361 & 8.0 & 451 & 321 & 0.179 & 29.5 \\
\hline 4 & 0.375 & 8.12 & 468 & 333 & 0.188 & 29.2 \\
\hline 5 & 0.623 & 8.04 & 476 & 338 & 0.191 & 30.2 \\
\hline 6 & 0.466 & 7.88 & 467 & 331 & 0.187 & 29.2 \\
\hline 7 & 0.085 & 8.12 & 487 & 345 & 0.194 & 29.5 \\
\hline 8 & 0.244 & 8.02 & 504 & 363 & 0.205 & 27.8 \\
\hline
\end{tabular}


TABLE 4. Laboratory test results of the water quality of Belik River.

\begin{tabular}{|c|c|c|c|c|c|c|}
\hline No & Discharge $\left(\mathrm{m}^{3} / \mathrm{s}\right)$ & Nitrate $\left(\mathrm{NO}_{3}, \mathrm{ppm}\right)$ & Sulfate $\left(\mathrm{SO}_{4}, \mathrm{ppm}\right)$ & Phosphate $\left(\mathrm{PO}_{4}, \mathrm{ppm}\right)$ & $\mathrm{BOD}(\mathrm{ppm})$ & $\operatorname{COD}(\mathrm{ppm})$ \\
\hline \multicolumn{2}{|c|}{ Class II Water Quality Standard } & 10 & 400 & 0.2 & 3 & 25 \\
\hline 1 & 0.076 & 2.29 & 2.039 & 46.188 & 4.478 & 22.23 \\
\hline 2 & 0.523 & 3.84 & 2.767 & 13.632 & 9.144 & 13.34 \\
\hline 3 & 0.361 & 0.18 & 5.777 & 22.77 & 1.139 & 23.5 \\
\hline 4 & 0.375 & 4.95 & 2.767 & 34.193 & 4.217 & 27.31 \\
\hline 5 & 0.623 & 2.91 & 1.796 & 35.145 & 7.657 & 45.1 \\
\hline 6 & 0.466 & 2.85 & 1.942 & 30.005 & 2.352 & 23.5 \\
\hline 7 & 0.085 & 2.23 & 3.398 & 35.716 & 4.457 & 14.61 \\
\hline 8 & 0.244 & 1.61 & 2.233 & 30.195 & 6.656 & 19.69 \\
\hline
\end{tabular}

BOD and COD represents contamination that reduces its capacity to support fishing and agricultural activities (Effendi et al. 2015). The laboratory test results of the water quality in Belik River are presented in detail in Table 4.

The laboratory test results of the water quality at each sampling point are illustrated in Figure 2. In general, each parameter measured in this study received input from domestic wastes generated by housing or residential areas, commercial establishments, and office complexes, including the wastewater discarded after using the bathrooms and toilets and in washing and cooking activities (Sugiharto 1987; Mckinney 2004). This condition corresponds to the majority of the land use that forms a densely populated urban region in the study area. Domestic wastewater is more challenging to control than its industrial counterpart because of its diffuse nature (Mukhtasor 2007; Cahyadi et al. 2011; Putri et al. 2018). Points 4, 5, and 6 are sampling sites located before/upstream, next to, and downstream of Langensari Reservoir. The laboratory test results showed that the levels of nitrate, sulfate, phosphate, BOD, and COD at Point 4 were higher than Point 6 . This finding proves the process of self-purification by the reservoir.

\section{CONCLUSIONS}

Belik Sub-watershed is an urban area with built-up land covering $91 \%$ of its total area. The dominant land uses are settlements and office complexes, meaning that an enormous volume of domestic waste enters the drainage system. Based on the water quality test results at eight sampling points, the nitrate and sulfate levels have not exceeded the Class II water quality requirements (Republic of Indonesia Government Regulation No. 82 of 2001), but the phosphate content is beyond its allowable presence in these standards. Very high phosphate concentrations are attributable to the domestic wastes introduced into the river, in particular, laundry detergents from the surrounding residential areas and laundry businesses. Also, the BOD of all sampling sites, except for Points 3 and 6 , is above the upper threshold set in the Class II water quality standard, that is, 3 ppm. Points 4 and 5 have indicated water pollution as their COD levels are higher than its allowable presence, namely $25 \mathrm{ppm}$.

\section{ACKNOWLEDGMENTS}

This research is part of the Faculty of Geography Lecturer's Research Grant (Hibah Penelitian Dosen Fakultas Geografi Tahun 2018, Universitas Gadjah Mada), entitled "Kajian Karakteristik Limbah Domestik Kali Belik (Kali Ma- nunggal) Kota Yogyakarta". Authors gratefully acknowledge the research funding and support from the Faculty of Geography, Universitas Gadjah Mada.

\section{REFERENCES}

Abdi Z, Hadi P, Widyastuti M. 2011. Kajian daya tampung beban pencemaran Sungai Batanghari pada Penggal Gasiang - Sungai Langkok Sumatera Barat [Carrying capacity of contaminant load Batanghari River at the Gasiang Segment - Langkok River, West Sumatera]. Majalah Geografi Indonesia. 25(1):1-25. doi:10.22146/mgi.1 3366.

Asdak C. 1995. Hidrologi dan pengelolaan daerah aliran sungai [Hydrology and watershed management]. Yogyakarta: UGM Press.

Asrifah D. 2012. Evaluasi potensi airtanah bebas untuk penyediaan air di Kalasan dan Prambanan [Unconfined groundwater potential evaluation for water supply in Kalasan and Prambanan]. Majalah Geografi Indonesia. 27(1):56-78. doi:10.22146/mgi.13448.

Bianchi E, Dalzochio T, Simões LAR, Rodrigues GZP, da Silva CEM, Gehlen G, do Nascimento CA, Spilki FR, Ziulkoski AL, da Silva LB. 2019. Water quality monitoring of the Sinos River Basin, Southern Brazil, using physicochemical and microbiological analysis and biomarkers in laboratory-exposed fish. Ecohydrology and Hydrobiology. 19(3):328-338. doi:10.1016/j.ecohyd.2019.05.002.

Cahyadi A. 2019. Analisis kerentanan airtanah terhadap pencemaran di pulau koral sangat kecil dengan menggunakan metode GOD [Groundwater vulnerability analysis in very small coral island using GOD method]. Jurnal Geografi. 16(1):48-53. doi:10.15294/jg.v16i1.18411.

Cahyadi A, Priadmodjo A, Yananto A. 2011. Criticizing the conventional paradigm of urban drainage. Proceeding the 3rd International Graduated Student Conference on Indonesia. Yogyakarta: Postgraduate School, Universitas Gadjah Mada. p. 547-553.

Cahyo PN, Hadi MP, Adji TN. 2016. Pengaruh potensi sumberdaya air terhadap pola penggunaan kebutuhan domestik di Kecamatan Eromoko, Kabupaten Wonogiri [The effect of water resources to the pattern of domestic water demand in Eromoko, Wonogiri]. Majalah Geografi Indonesia. 30(2):196-206. doi:10.22146/mgi.156 49.

Effendi H. 2003. Telaah kualitas air: bagi pengelolaan sumber daya alam dan lingkungan perairan [Water quality analysis for natural resources and water environment]. Yogyakarta: Kanisius.

Effendi H, Romanto, Wardiatno Y. 2015. Water quality sta- 
tus of Ciambulawung River, Banten Province, based on pollution index and NSF-WQI. Procedia Environ Sci. 24:228-237. doi:10.1016/j.proenv.2015.03.030.

Fardiaz S. 1992. Polusi air dan udara [Water and air pollution]. Yogyakarta: Kanisius.

Kuo YM, wen Liu W, Zhao E, Li R, Muñoz-Carpena R. 2019. Water quality variability in the middle and down streams of Han River under the influence of the Middle Route of South-North Water diversion project, China. J Hydrol. 569:218-229. doi:10.1016/j.jhydrol.2018.12.001.

Mckinney RE. 2004. Environmental pollution control microbiology. New York: Marcell Dekker.

Mukhtasor. 2007. Pencemaran pesisir dan laut [The contamination of sea and coast]. Jakarta: Pradnya Paramita.

Prihatin RB. 2016. Alih fungsi lahan di perkotaan (studi kasus di Kota Bandung dan Yogyakarta) [Land use change in urban area (case study: Bandung and Yogyakarta). Jurnal Aspirasi. 6(2):105-118. doi:10.22212/aspirasi.v6i2.5 07.

Puspita I, Ibrahim L, Hartono D. 2016. Pengaruh perilaku masyarakat yang bermukim di kawasan bantaran sungai terhadap penurunan kualitas air sungai Karang Anyar, Kota Tarakan [The effect of riverside inhabitant to water quality degradation in Karang Anyar River, Tarakan]. Jurnal Manusia dan Lingkungan. 23(2):249258. doi:10.22146/jml.18797.

Putri MA, Risanti AA, Cahyono KA, Latifah L, Rahmawati N, Ariefin RF, Prameswari S, Waskita WA, Adji TN, Cahyadi A. 2018. Sistem aliran dan potensi airtanah di seba- gian desa Sembungan ditinjau dari aspek kuantitas dan kualitas [Flownet and groundwater potential in Sembangun Village from the quality and quantity perspective]. Majalah Geografi Indonesia. 32(2):155-161. doi: 10.22146/mgi.32297.

Setiawan AD, Widyastuti M, Hadi MP. 2018. Water quality modeling for pollutant carrying capacity assessment using Qual2Kw in Bedog River. Indones J Geogr. 50(1):49-56. doi:10.22146/ijg.16429.

Shi B, Bach PM, Lintern A, Zhang K, Coleman RA, Metzeling L, McCarthy DT, Deletic A. 2019. Understanding spatiotemporal variability of in-stream water quality in urban environments - a case study of Melbourne, Australia. J Environ Manage. 246:203-213. doi:10.1016/j.je nvman.2019.06.006.

Sugiharto. 1987. Dasar-dasar pengelolaan air limbah [Fundamentals of waste water management]. Jakarta: UI Press.

Suprayogi S. 2017. Analisis banjir Segmen Sungai Winongo akibat perkembangan wilayah menggunakan HEC-RAS [Analysis in Winongo River segment caused by urban sprawl]. Technical report. Faculty of Geography, Universitas Gadjah Mada. Yogyakarta.

Sutardi A, Suprayogi S, Adji TN. 2017. Kajian Kualitas Airtanah Bebas antara Sungai Kuning dan Sungai Tepus di Kecamatan Ngemplak, Yogyakata, Indonesia [Unconfined Groundwater quality analysis between Kuning and Tepus River in Ngemplak, Yogyakarta]. Majalah Geografi Indonesia. 31(1):31-38. doi:10.22146/mgi.24230. 